\title{
Evaluating the Classification of Economic Activity into Recessions and Expansions
}

\section{Travis J. Berge and Òscar Jordà}

\section{Web Appendix}

\section{A. Data Sources and Calculations}

This is a summary of the economic indicators, transformations and data sources provided in the appendix of the December 11, 2008 press release of the Business Cycle Dating Committee of the National Bureau of Economic Analysis and available from their website (www.nber.org).

\begin{tabular}{|c|c|c|}
\hline Indicator & Sample Available & Source and Method \\
\hline Industrial Production & 1919:1 - 2009:10 & FRB index B50001 \\
\hline $\begin{array}{l}\text { Real Personal Income less trans- } \\
\text { fers }\end{array}$ & 1959:1 - 2009:5 & $\begin{array}{l}\text { BEA Table } 2.6 \text {, line } 1 \text { less line } 14 \text {, both de- } \\
\text { flated by a monthly interpolation (see below) }\end{array}$ \\
\hline Payroll Employment & 1939:1 - 2009:10 & $\begin{array}{l}\text { of BEA Table } 1.1 .9 \text { line } 1 \\
\text { BLS Series CES0000000001 (Septem- } \\
\text { ber and October } 2009 \text { preliminary) }\end{array}$ \\
\hline Household Employment & 1948:1 - 2009:10 & BLS Series LNS12000000 \\
\hline $\begin{array}{l}\text { Real Manufacturing and Trade } \\
\text { Sales }\end{array}$ & 1997:1 - 2009:9 & BEA Table 2BU, line 1 \\
\hline Real Gross Domestic Product & 1947:I - 2009:III & $\begin{array}{l}\text { BEA Table } 1.1 .6 \text {, line } 1 \text { (2009:III ad- } \\
\text { vance estimate) }\end{array}$ \\
\hline Real Gross Domestic Income & 1947:I - 2009:III & $\begin{array}{l}\text { BEA Table } 1.10 \text {, line } 1 \text {, divided by BEA Ta- } \\
\text { ble } 1.1 .9 \text {, line } 1 \text { ( } 2009 \text { :III advance estimate) }\end{array}$ \\
\hline
\end{tabular}

Websites:

- Federal Reserve Board industrial production index: www.federalreserve.gov/releases/g17/iphist/iphist_sa.txt

- Bureau of Economic Analysis, U.S. Department of Commerce, all but sales: www.bea.gov/national/nipaweb/SelectTable.asp?Selected $=\mathrm{N}$ Sales: www.bea.gov/national/nipaweb/nipa_underlying/SelectTable.asp

- BLS payroll survey: http://data.bls.gov/cgi-bin/surveymost?ce

- BLS household survey: http://data.bls.gov/cgi-bin/surveymost?ln

\section{Interpolation of GDP deflator:}

The value of the index in the first month of the quarter is one third of the past quarter's value plus two-thirds of the current quarter's value. In the second month, it is the quarter's value. In the third month, it is two-thirds of the quarter's value plus one third of the next quarter's value. 
Indices

\begin{tabular}{lll}
\hline \hline Indicator & Sample Available & Source and Method \\
\hline Chauvet-Hamilton Index & $1967: 11-2009: 2$ & Chauvet and Hamilton (2005) \\
Chauvet-Piger Index & $1967: 2-2009: 9$ & Chauvet and Piger (2008) \\
$\begin{array}{l}\text { Aruba Diebold Scotti Index } \\
\text { Chicago Fed National Activity In- }\end{array}$ & $1960: 2-2009: 10$ & Federal Reserve Bank of Philadelphia \\
dex & & Federal Reserve Bank of Chicago \\
Purchasing Managers Index & $1948: 1-2009: 10$ & \\
\hline \hline
\end{tabular}

\section{Websites:}

- Chauvet-Hamilton Index:

http://www.econbrowser.com/archives/rec_ind/description.html

- Chauvet-Piger Index:

http://www.uoregon.edu/ jpiger/us_recession_probs.htm

- ADS Index:

http://www.philadelphiafed.org/research-and-data/real-time-center/ business-conditions-index/

- Chicago Fed Index:

http://www.chicagofed.org/economic_research_and_data/cfnai.cfm

- Purchasing Managers Index: http://www.ism.ws/ 


\section{Conference Board Index of Leading Indicators}

\begin{tabular}{l|l}
\hline \hline Indicator & Sample Available \\
\hline Average weekly hours, manufacturing & $1939: 1-2009: 6$ \\
Average weekly initial claims for unemployment insurance & $1967: 1-2009: 6$ \\
Building permits, new private housing units & $1960: 1-2009: 6$ \\
Index of supplier deliveries—vendor performance & $1948: 1-2009: 6$ \\
Interest rate spread, 10-year Treasury bonds less federal funds rate & $1954: 8-2009: 6$ \\
Manufacturer's new orders, consumer goods and materials & $1959: 1-2009: 6$ \\
Manufacturer's new orders, nondefense capital goods & $1959: 1-2009: 6$ \\
Money supply, M2 & $1959: 1-2009: 6$ \\
Stock prices, S\&P 500 & $1921: 1-2009: 6$ \\
University of Michigan index of consumer expectations & $1959: 11-2009: 6$
\end{tabular}

\section{The LexisNexis News Index:}

The index is a standardized count of the number of news items that appear in the LexisNexis Academic database (see http://www.lexisnexis.com/us/lnacademic). In particular, the count is the number of news articles or news abstracts that LexisNexis retrieves when searching for the word "recession" within "US Newspapers and Wires" source. Our database is at a monthly frequency, beginning in July 1970 and running through June 2009. Each monthly observation is the average daily count for all days within that month, which we then standardize by removing a time trend and adjusting for seasonal variation in the number of counts.

The Principal Components Index: The Principal Components Index is constructed by performing principal components decomposition on the covariance matrix associated with the seven indicators explicitly considered by the BCDC. The sample period for the Principal Components Index is February 1967-August 2009 for the month-on-month index. The sample begins in January 1968 for the index based on the annual growth rates of the indicators, with the different start date due to the difference in the number of log-differences taken when smoothing the data. 